\title{
Publisher Correction: A human monoclonal antibody blocking SARS-CoV-2 infection
}

\author{
Chunyan Wang, Wentao Li (D), Dubravka Drabek (1D, Nisreen M. A. Okba (1), Rien van Haperen, \\ Albert D. M. E. Osterhaus, Frank J. M. van Kuppeveld, Bart L. Haagmans (D), Frank Grosveld \& \\ Berend-Jan Bosch (1D
}

Correction to: Nature Communications https://doi.org/10.1038/s41467-020-16256-y, published online 4 May 2020.

The competing interests section of the original article contained an error. In the sentence "A patent application has been filed on 12 March 2020 on monoclonal antibodies targeting SARS-CoV-2 (United Kingdom patent application no. 2003632.3”, the number 2003632 was hyperlinked in error to an irrelevant page. The link has been removed both from the PDF and the HTML version of the article.

Published online: 14 May 2020

Open Access This article is licensed under a Creative Commons Attribution 4.0 International License, which permits use, sharing, adaptation, distribution and reproduction in any medium or format, as long as you give appropriate credit to the original author(s) and the source, provide a link to the Creative Commons license,
and indicate if changes were made. The images or other third party material in this article are included in the article's Creative Commons license, unless indicated otherwise in a credit line to the material. If material is not included in the article's Creative Commons license and your intended use is not permitted by statutory regulation or exceeds the permitted use, you will need to obtain permission directly from the copyright holder. To view a copy of this license, visit http://creativecommons.org/licenses/by/4.0/.

(C) The Author(s) 2020 